\title{
Lord of Kedar
}

"Not far from Gaurikund, in between mountain peaks in the Mandakini valley, lies the Shri Kedarnath temple that is known as Kailasa, the original, eternal dwelling place of Bhagwan Shankar-Ji. There is no linga or image [Hindi: murti] here, there is only a high place [Hindi: sthan] in a three-sided shape ${ }^{1}$ that is known as the back side of Shiva-Ji's buffalo." This excerpt from a modern pilgrim's guide points to the difficulty of expressing in precise language the exact textures and details of Shiva's form and presence in Kedarnath. Another example comes from the interview with Kedarnath tirth purohit Tiwari-Ji mentioned in the previous chapter. He said about the shape of the linga: "It is the formless shape of God [Hindi: Bhagwan].... It was here from before, it is as if it comes from the ground, it is the real linga.... And [it is formless] so that people will not leave assuming that the linga has a particular form. ... ${ }^{2}$ Ghee is also important here. They [the visitors] are ... laying on their hands [anointing the linga with ghee]." A third example arose in conversation with an elderly Kedarnath valley man who had spent numerous seasons in Kedarnath. He expressed the place/practice relationship in this way:

Inside the temple there is a mountain. It is the Himalaya mountain inside the temple. And the God [Hindi: Bhagwan] there means the mountain. Whatever divine power [Hindi: qudrat] is there, that qudrat takes the form of God. But if you say to someone, "Worship a mountain," he won't do it, will he? "Worship the mountain," brother, no one will do it. What we old people did is we put the mountain inside the temple. We took that very mountain and built an impressive temple there, where now people come and exclaim, "Vah vah, what an enormous linga!" That's whose puja we do-we are doing the puja of the Himalaya. We do the puja of that lap of Himalaya in which we live. 
Shiva's form and presence in Kedarnath, today, are marked with ambiguity. He is both formless and formed from the mountainous place, a rock in the ground. These accounts attest to this material ambiguity and connect it to one of the most memorable and distinctive pieces of modern ritual practice associated with Kedarnath: that everyone who enters the temple in the morning is allowed to massage ghee into the linga (a practice I discuss in more detail in chapter 4) with his or her own hands as an encounter with the formless, fluid materiality of Shiva's linga presence. Commercial visual culture in Kedarnath, about which I have written in detail, attests to this same ambiguous materiality (Whitmore 2012). What does it mean to say that Shiva is "in" the Himalaya, that he is "present" in a specific location? ${ }^{3}$ What has it meant at different moments in the past? While anthropomorphic representations of Shiva are widespread, today it is fair to say that the linga is Shiva's primary form in our world (Bisschop 2009, 751). If, however, we think back to the second half of the first millennium CE in South Asia, it becomes a bit more difficult to envision exactly how Shiva's presence in the Himalaya was understood and experienced.

The recorded story of Shiva's ambiguously formed hyperpresence in the Himalayan landscape of Kedarnath began in the first millennium CE, when different Shaiva groups were imagining and engaging Shiva (and the earlier deity to which he was connected, Rudra) in diverse ways. The forms in which he was depicted and worshipped were during this period in considerable flux. ${ }^{4}$ The second half of the first millennium CE in the Indian subcontinent was a time when numerous Shiva-oriented social formations, ways of depicting and imagining Shiva, and systems of Shiva-oriented ritual and philosophical thought were developing in dynamic and fluid ways. The increasing importance of Shaiva religious specialists and nascent institutional networks to politically astute kings influenced these developments. Much of this Shaiva world had begun to be present in the central Indian Himalaya and intersected in some way or other with Kedarnath.

Paying close attention to Shiva's ambiguity of form, and the multiple ways in which that form and presence were understood to connect to the Himalayan landscape, is important because these early understandings of form and presence functioned as one of the "initial conditions" of the complex eco-social system of Kedarnath. In their consideration of the application of the "science of chaos" to the practices of social anthropology, Frederick Damon and Mark Mosko $(2005,7)$ have noted that "sensitive dependence on initial conditions" is one of the hallmarks of chaotic phenomena. Tracing out these early patterns, while keeping in mind their continuously contingent and emergent character, is helpful for thinking about the present and recent past of this place. With this goal in mind, therefore, I review how early chapters in the history of Shaivism intersected with both Kedarnath specifically and the regions known today as Garhwal and Kumaon more broadly. 
As Shiva-oriented myth, ritual practice, behavior, and philosophy moved into the second half of the first millennium CE and the second millennium CE, the surfeit of Shiva's powerful presence in the Himalaya began to mesh with the more general religious power of the Himalaya, multiple forms of the Goddess (some of the most important of whom are rivers), and the deity Bhairava. Multiple ways of understanding the nature and forms of Shiva, the Goddess, and Shaiva and Shakta (Goddess-related) deities and beings of power intersected in premodern constructions, imaginations, and experiences of Kedarnath. The place was not stamped by the worldview of a single group. Numerous relationships between deity, devotee, and place were imagined: relational, instrumental, devotional, mystical, alchemical, and nondual. My discussion of premodern Shaiva history of Kedarnath in a book that focuses on the twenty-first century is not meant to erase the historical distance between $600 \mathrm{CE}$ and the late twentieth and early twenty-first centuries. Rather, I want to suggest that in the second half of the first millennium CE the overlapping of early understandings of Shiva's form with understandings of his presence in Kedarnath created a formative and foundational set of mythological, social, philosophical, symbolic, and material parameters.

\section{SIXTH CENTURY CE}

Let us imagine, then, what might have been evoked for someone living during the sixth century CE somewhere in the Indian subcontinent who had an interest in Shiva and heard about a place known as Kedara, associated with Shiva and located in the Himalaya. This was a time when much of what we would now call North India was in considerable flux. The vast Gupta Empire had begun to come apart, and newer and smaller rulers were stepping into its place. Because the Gupta emperors had officially been devotees and patrons of the god Vishnu, this meant that it made sense for newer and competing political formations to ally themselves with a different religious power, and Shiva in many places became the deity of choice (Bakker 2014, 4). The fifth and sixth centuries CE marked the beginning of what Alexis Sanderson $(2009,44)$ has termed "the Saiva Age, " the age of the "dominance of Śaivism" (see also Fleming 2009b, 53). Hans Bakker $(2014,1-4,10)$ and his team of researchers have recently shown that early manuscript versions of the Sanskrit text of the Skandapurana, a text that prominently describes Shiva's presence in the Himalaya and that generally wanted to "sanctify the landscape of northern India," both chronicled and helped shape the beginning of this new phase.

By this time a fierce deity called Rudra, a god with an uneasy relationship to many of the deities in the pantheon of divine beings who are described in and whose worship is enjoined in early Vedic texts, had come to be known as what Peter Bisschop $(2009,742)$ calls an "all-god"-the single being who is the source of all and to whom all devotion and religious attention must eventually be directed. 
This Rudra came eventually to be known by names such as Mahadeva, Maheshvara, Sthanu, and Shiva. Shiva preferred to live in and around Mount Kailasa in the Himalaya as a solitary yogi and often expressed a preference for human and divine devotees who were inhabitants of the borderlands: non-Aryan local peoples and their non-Vedic local deities and supernatural beings, what Geoffrey Samuel (2008, 101-2) has termed local "guardian" and "protective" deities. Shiva was also beginning to display, somewhat paradoxically, both a personality committed to asceticism and solitude and at the same time an often erotic partnership with the daughter-in-law of the Himalaya: the goddess Parvati. As Benjamin Fleming (2009a, 444) has pointed out, this tension can be read in two different ways: as a synthesis in which over time the several different groups' portrayals of Shiva became fused in a single complex account and/or as a kind of mythological Moebius strip that offers insight into the ahistorical metaphysics of the god's deeper nature. Some groups at this time worshipped Shiva as an independent being, and others had begun to envision Shiva as a god who existed in special relationship to forms of the Goddess (Devi, Mahadevi, Parvati, shakti), who were themselves coming to occupy a more prominent place in those religious worlds that in the mid-first millennium CE were found in Puranic, epic, and agamic genres of Sanskrit texts.

In one of his most famous stories Shiva marries Parvati in her incarnation of Sati, the daughter of the great divine king Daksha, son of the creator god Brahma, who does not like his disreputable new son-in-law. Daksha does not invite him to the great fire sacrifice, even though he invites all the other gods. Sati (Parvati) becomes so incensed at this affront to her husband that in many versions of this story she kills herself. Shiva, upon hearing of the death of his wife, sends a personification of his anger (the deity Virbhadra, another early form of Bhairava) along with his fierce supernatural troops (Sanskrit: gana) to destroy the sacrifice of Daksha. Daksha ultimately becomes a devotee of Shiva after Shiva cuts off his head and replaces it with that of a goat. Shot through this story, and many other such mythological narratives of first-millennium CE South Asia, are complicated tensions between the Brahminical order (here represented by Daksha, the descendant of Brahma) and the diverse non-Brahmin human constituencies of Shiva. Shiva appears as the antinomian deity who lives beyond the geographical and social boundaries of the Brahmin-centric Vedic world and its affinity for the stability offered by Vishnu, and the place-based deities of his non-Brahmin constituencies often became his ganas. The putative location of Daksha's sacrifice, near the modern town of Kankhal at the lower edge of modern-day Garhwal, was already an important location for devotees of Shiva in approximately the sixth century CE (Bakker 2014, 173-81). Also woven into this competitive and diverse socioreligious milieu were numerous Buddhist and Jain communities. 
Kedara-related names for Shaiva places were already multiple. Variations on the name Kedarnath that connected to a place or temple of Shiva already existed in many places in South Asia and as far away as Cambodia by the middle of the seventh century CE (Bisschop 2006, 35, 181; Fleming 2009b, 64-65). Peter Bisschop (2006, 14) has demonstrated, through his examination of early manuscript versions of the Skandapurana dating back to the ninth century, that possibly already between the sixth and ninth centuries CE Kedarnath (in that text referred to as Kedareshvara), by virtue of its presence on these ayatana lists, was known as a place of Shiva in the Himalaya. These early manuscripts of the Skandapurana place a great deal of emphasis on the Garhwal Himalaya. ${ }^{5}$

There are no conclusive references to Kedarnath as a Himalayan place that link conclusively to the Pandavas in early versions of the Sanskrit Mahabharata, arguably one of the oldest records of the established practice of pilgrimage in South Asia (Vassilkov 2002, 135). Kedarnath is, however, mentioned in connection with the Great Departure and eventual journey on the Great Path of the Pandavas into heaven in what Peter Bisschop $(2006,181)$ has assessed as "probably a relatively late interpolation," leading him to state, "We can conclude that Kedāra is absent in the MBh's [Mahabharata] lists of pilgrimage places, and thus the sanctity of Kedāra was recognized only after the normative redaction of the MBh." In the midst of a description of the Pandavas' Himalayan yatra that includes several other residences of Shiva that could arguably be located in the Garhwal Himalaya, part of the interpolated Mahabharata passage relates the following about their visit to Kedarnath:

After making reverence to Shiva [Sanskrit: Ishana] they bathed in the swan-water [Sanskrit: hamsodake, possibly some sort of special liquid]. Having seen the god of gods, Kedara, making an effort they touched him. After offering balls of food [Sanskrit: pindam] to their ancestors in the proper manner and making offerings [Sanskrit: tarpya] for their ancestors and for the gods, they drank water in the proper manner and went to the river Nanda. Then he [in my reading, Yudhishthira], having turned toward the Great Path, went to the place of snow. ${ }^{6}$

The fact that the Pandavas drink water in Kedarnath is notable. A particular connection with water is also one of the oldest things we know about the Himalayan Kedarnath. Early manuscripts of the Skandapurana introduce Kedarnath in this way just after describing the abode of Shiva at Mahalaya, an unidentified site that Bisschop notes may be suggestively but not conclusively connected to the modern shrine of Rudranath, which is today counted as one of the Panch Kedar, the system of five Shaiva temples in central Garhwal that includes Kedarnath. Here is the passage, in Bisschop's (2006, 66, for commentary, see 180-81) translation:

More holy is Kedāra, which lies to the north of it, the supreme abode of Vṛșānka. There Hara [Shiva] himself released the holy water from the mass of his matted hair. Men who drink that water become Gaṇas, Kuṣmāṇḍas, dear ones to Rudra. Brahmā, 
Śakra, Viṣnu, Soma and Kubera praise Parameśvara who is present there. They who take pleasure in adharma do not get to drink the water which streams from the head of Vibhu without Siva's favour, but those who have drunk it are released from the fear of the chains of existence.

Kedarnath was one of the locations where it was believed that Ganga descended into the human world. Bisschop $(2006,182)$ further notes that "the liberating power ascribed to drinking the water at Kedāra is a recurrent theme in the Puranic descriptions of Kedāra." 7 By approximately the seventh century CE, Kedarnath in the Himalaya was known in the Tamil-speaking regions of South India as a mountainous place of water: an emphasis on water is found in a verse by the seventh-century Tamil poet Campantar: "on Kētāram, its peaks replete with water, where the unblinking celestials dwell." ${ }^{8}$ Thus, in the earliest mentions of Kedarnath in the Himalaya, Shiva is present but not the only powerful entity of note. The efficacious place of Kedarnath also connects with the waters of the Ganga and the Himalaya more generally. The power of the place in this description is premised on the presence of Shiva but does not solely derive from him.

While the above Skandapurana passage refers to an anthropomorphic Shiva with "matted hair," it is important to realize that early Shiva-oriented groups worshipped and envisioned Shiva in more than one form, only some of which were anthropomorphic (Acharya 2009, 465; Bisschop 2009, 744, 746-47; Bakker 1997, 75-76). Benjamin Fleming (2009a, 444-45) artfully summarizes the complex situation in this way: "In the relevant materials dating from the second century BCE to the sixth century CE, there is no one dominant or consistent form. Nevertheless, one may see a general trend in the extant evidence: phallic imagery is gradually downplayed and abstracted over time." Different forms and combinations of Shiva were being created and worshipped at this time: an anthropomorphic figure with a club, an aniconic linga, a linga with an anthropomorphic figure emerging out of it, a linga with four or five faces (Srinivasan 1997, 260-81). Traces of this transformation in form and understanding can be seen in a famous story of Shiva that is often connected to Kedarnath. Vishnu and Brahma are arguing about who is more powerful. Suddenly a column of light appears. They decide that whoever can find the end of the column of light first is more powerful. The column of light is revealed to be unending, and Vishnu and Brahma must admit defeat. The column of light, it turns out, is Shiva in his jyotirlinga form, and this mythological narrative attests to both the rise of Shaivism and the transformation of understandings of the linga form during the multiple redactions of the Puranas that were under way throughout much of the first millennium CE.

This ambiguity of form was attested during the growth of a transregional network of sacred Shaiva pilgrimage places. Fleming (2007, 81-84) has shown, in part with specific reference to Kedarnath, that during the later redactions of the different parts and versions of the Shiva Purana (the Sanskrit text in which some of 
the most famous stories relating to Kedarnath and other Shaiva tirthas are found) it was not wholly clear exactly what was meant by the term linga or whether a linga was the only aniconic form taken by Shiva in the world. He has insightfully elucidated how the idea of the jyotirlinga, the linga made of light, represented a transformation of Vedic fire and earth worship into linga worship. Fleming has also demonstrated that the system of the twelve jyotirlinga tirthas knit preexisting somewhat separate Shaiva sites and various modes of worship in different parts of medieval South Asia into a single network of twelve places, the twelve jyotirlinga, that came to be understood as part of a single overarching Shaiva framework of sacred geography and religious practice. ${ }^{9}$ This system naturalized the conflation of Shiva's various material forms (i.e., the forms through which he could be approached in ritual: linga, clay ball, fire, light, and different forms of earth) into the idea of the jyotirlinga system (Fleming 2007, 137, 167-69). Fleming concludes that this "cult of the jyotirlingas" arose between the tenth and thirteenth centuries (2).

\section{EARLY SHAIVA GROUPS}

Early Shaiva groups imagined a number of possible outcomes of their devotion to and focus on Shiva: for lay devotees material benefit in this life, residence in "the deity's paradise" after death, or a high-quality rebirth, and for the initiated nonlay practitioner "the attainment of the non-finite goal of liberation" (Sanderson 2013, 212). The "larger, lay Śaiva community" were sometimes termed "Followers of the Great Lord" ("Great Lord," in Sanskrit Maheshvara, is a common epithet for Shiva) (Bisschop 2010, 485; Bakker 1997, 70-79). Early “initiatory Śaivism” took two main paths, each with several branches: there were the systems of the "Outer Path" (Sanskrit: Atimarga) and the systems of the "Path of Mantras" (Sanskrit: Mantramarga) (Sanderson 2013, 212; Sanderson 1988, 664). One important early Atimarga Shaiva group, well attested by the fourth century CE, called themselves the Pashupatas (Acharya 2009, 464). The Pashupatas took their name from the epithet "Lord of Cattle/Beasts" (Sanskrit: Pashupati), one of the Vedic names of the deity Rudra that is often invoked in debates about the identity of the horned deity depicted on Indus valley seals and the connection of that deity to Shiva (Bisschop 2009, 741). The Pashupatas were Brahmin men who had renounced worldly life and envisioned themselves as the cattle of Rudra-Shiva. They engaged in extreme devotion to Rudra, physically imitated the actions of bulls, and recited Shiva-focused mantras. As Diwakar Acharya $(2009,459)$ puts it, "All initiates were ascetics, and all practice was aimed ultimately at liberation. Even though supernatural powers were achieved early on in their practice, a Pāśupata initiate was supposed to continue with his original quest for the end of suffering." This basic system in turn produced different Pashupata schools, one of which came to hold the influential view that the legendary figure of "the Lord with a Club" (Sanskrit: 
Lakulisha), an "otherwise unnamed incarnation of Siva," was the founder of the Pashupata system (Acharya 2009, 461). Lakulisha Pashupatas were also sometimes known as "Dark-Faced Ones" (Sanskrit: Kalamukha), a term that would become more important as time went on (Sanderson, 2013, 212).

The Mantramarga branches were also deeply involved in the formative early history of Shaiva traditions (Sanderson 1988, 664, 667). One Mantramarga group produced what would come to be known as the Shaiva Siddhanta system, associated with a set of Shiva-focused ritual and philosophical texts collectively called the agama and later more broadly with what would come to be termed tantric Shaivism. Their approach focused on teaching the initiated practitioner how to gradually, through the progression of a series of ritual and meditative stages, attain union with and/or transform into Shiva, the universal source of all, and thereby achieve "final liberation" (Davis 1991, 83). While today Shaiva Siddhanta traditions are thought of primarily as primarily South Indian, in the first chapter of the history of the Shaiva Siddhanta their denominations constituted a network that stretched across much of the subcontinent. They were adept at what Sanderson $(2013,213-14)$ has termed the "more visible" realms of religious practice of those on the Path of Mantras: administering temples and monasteries and strategically facilitating the ritual initiation of kings into the Shaiva community (see also T. Smith 2007). The Shaiva Siddhanta developed an important and influential overarching philosophical understanding of the nature of Shiva that was reflected in their iconography: that Shiva is both formed and formless (Davis 1991, 112-36).

By the ninth and tenth centuries some of the earlier networks of the Pashupatas had given way to those of the Shaiva Siddhantas. The Kalamukhas had also come to function as the inheritors of the Pashupata in many places across the subcontinent. By the ninth century they had already begun to be in positions of institutional authority in the region known today as Karnataka, and, while the historical record is not consistent, they appear to have focused on using transgressive behavior (ritual practice that involved interaction with impure substances, for example) as a way to move past the mundane distinctions of pure and impure (Sanderson 2013, 229-31; 1988, 666). ${ }^{10}$ As I illustrate later in this chapter, it is reasonable to conclude that each of these (themselves not monolithic) groups had some direct or indirect connection to or knowledge of Kedarnath. We know that there were pilgrimages by Pashupatas and Kalamukhas to Kedarnath (Bisschop 2006, 182; Lorenzen 1972, 109, 173).

\section{BHAIRAVA AND DEVI}

The second stream of the Mantramarga, some survivors of the Atimarga, and a third, more Goddess-focused stream, the "Esoteric Path" (Sanskrit: Kulamarga), over time came to focus to a greater extent on two additional figures of divine power who were also coming to be connected prominently to Shiva in this 
mid-first-millennium period (Sanderson 2013, 212-13). The first was the Goddess (Devi, Mahadevi, Parvati, Durga, Kali, Shakti) in her multiple forms. Today Goddess-oriented Shakta traditions are deeply intertwined with Vaishnava (Vishnu-oriented) and Shaiva traditions. In many important ways this intertwining strengthened in the first half of the first millennium CE as Brahminical traditions began to fuse and incorporate non-Brahminical local and regional deities and supernatural beings, many of whom were female. This synthesis became further formalized and naturalized in ritual, philosophical, and textual contexts in the second half of the first millennium CE.

Goddess-oriented theisms are perhaps most famously attested in the Devi Mahatmya of the Markandeya Purana, which relates the victory of the warrior goddess Durga over demon foes whom the gods had been unable to vanquish. The forms of the Goddess most commonly associated with Shiva are Parvati (the god's marriage partner), Kali (one of the fierce manifestations of the anger of the Goddess), and shakti. In Puranic literature shakti can be presented either as a kind of energy, force, or anger or in personified form as a specific goddess. In personified form a shakti is presented both as an independent being and as the consort/partner of a god such as Vishnu or Shiva. The marriage of a local goddess with a god such as Vishnu or Shiva and the assimilation of the local goddess into the more universal figure of Devi (Mahadevi, the Goddess, Shakti, etc.) constitute enduring themes in Puranic literature and are indices through which the mixing of ethnic group, culture, geography, and language characteristics of South Asian religious traditions in the medieval and modern periods is often investigated by scholars (Chakrabarti 2001; Shulman 1980). All of this connects very directly to Garhwal: as the work of William Sax (1991) has chronicled, Devi, in her numerous regionally and locally important forms, is ubiquitously present and active in the modern Garhwali Himalayan landscape in myriad forms of local and regional significance.

The second important deity with whom Shiva came to be associated was Bhairava, who begins to be attested in the textual and archaeological record in the fifth to seventh centuries CE (White 2009, 485). Bhairava was a guardian deity, a demon lord who was known to inhabit cremation grounds and who came to be understood as the chief of Shiva's monstrous troops of followers (Sanskrit: gana). Bhairava was a manifestation of Shiva's anger and hence a form of Shiva himself, and he became the focal point for Shaiva systems of thought and practice that focused on transgression as a tool for religious progress. Bhairava was famously associated with a group known as the Kapalikas, or "someone who carries or deals with a skull or skulls (kapāla) on a regular basis" (Törzsök 2011, 355). The Kapalikas tended to model themselves after and worship Shiva in his Bhairava form. Their name comes from the narrative detail that when Shiva's angry Bhairava form cut off one of the god Brahma's five heads, the skull (Sanskrit: kapala) then stuck to his hand, making him a kapalika. Bhairava/Shiva, to cleanse himself of the pollution of Brahminicide (killing the god Brahma is like killing a human Brahmin priest), 
wandered from place to place for twelve years until he came to the city of Varanasi, where Brahma's decapitated head fell off and Shiva's transgression was erased, thus narratively establishing Varanasi as a center of Shaiva importance.

To digress into the Uttarakhandi present for a moment, it should be noted that Bhairava (more commonly known today as Bhairav or Bhairavnath) is one of the most important deities in in modern-day Garhwal. Along with forms of Devi, in various guises he functions as one of the important and ubiquitous bridges between the worlds of the Puranas and the local and regional worlds of regions such as Garhwal, in which his ubiquitous forms are appealed to for justice and revenge (Sax 2009, 27-28). Sax (2009, 25-50) has observed, in the context of a study on the cult of Bhairava among Garhwali Harijans, that Bhairav is a primary focus of local devotion and a far more active presence in the daily lives of most Garhwalis than Shiva. His identity in Garhwal centers on his ability to provide protection and justice. More generally, his character as the lord of spirits residing at the edge of demarcated times and spaces and guarding the transitions is continuous with his character in Nepal. I was once discussing Bhairav's relationship to Shiva with two local employees of the local hydropower plant that, in the recent years preceding 2013, powered the government facilities at Kedarnath. I had been feeling confused as to whether, in the contexts of Kedarnath and the Kedarnath valley, Bhairavnath was actually another form of Shiva or whether it made more sense to regard him as a lieutenant of sorts. The analogy we reached in the conversation that was satisfactory to all parties was that Shiva was the actual electric generator powered by the flowing water-full of vast amounts of power. Bhairavnath was the electric heater warming us as we spoke, a heater powered by that electric generator. The heater is an obviously smaller conduit for electricity, yet there is no direct way of accessing the electricity present in the generator without plugging in a smaller, external device.

Bhukund Bhairavnath is the form of Bhairavnath resident in Kedarnath. ${ }^{11}$ His open-air shrine lies to the southeast of the Kedarnath temple at the lip of a small plateau that runs parallel to the main valley floor. Bhukund Bhairavnath is colloquially known as the lineage deity (Hindi: kul-devta) of the Kedarnath Tirth Purohit Association. The Kedarnath tirth purohits worship him with a havan and a puja several times each season, and these occasions are one of the most visible moments of the season, when the tirth purohits are in charge of the proceedings and the temple committee (the Samiti) is relegated to a secondary role. Indeed, one of the main local havans of 2007 serendipitously followed close on the heels of the day on which the Kedarnath Tirth Purohit Association received word that in their ongoing legal battle with the Samiti they had won an appeal at the Uttarakhand High Court in Nainital regarding their rights to collect ritual fees (Hindi: dakshina) in and around the temple. The shrine of Bhairavnath was open to the elements-every time the association asked him through his chosen human vehicle (Garhwali: naur) whether he would like them to build him a temple, he 


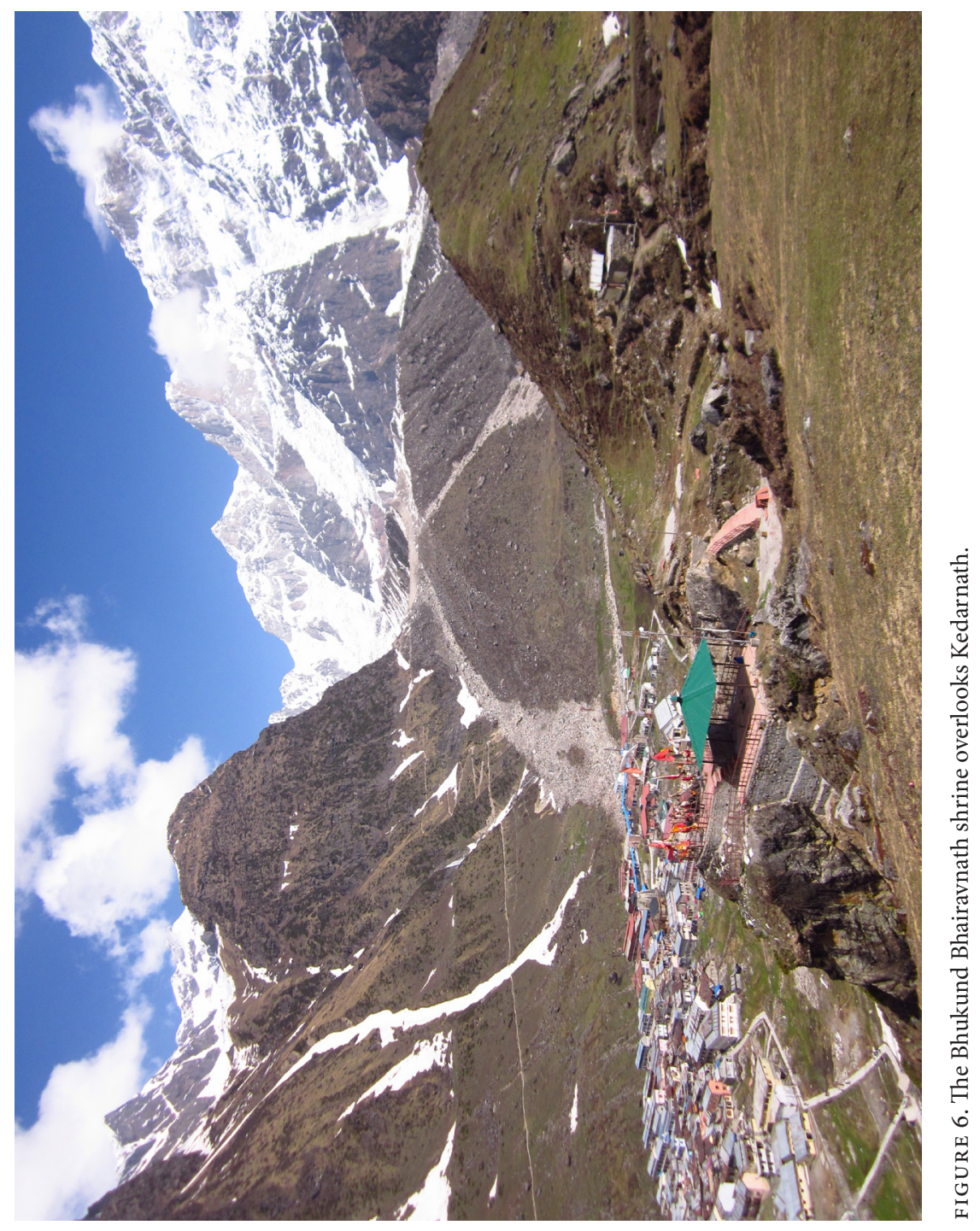


refused. I also noticed, reinforcing Bhukund Bhairavnath's character in Kedarnath as a protector, that several of the important police officers in Kedarnath would make a point of paying their respects to Bhairavnath while standing in the temple courtyard during shringar arati at the time when the pujari would offer the arati flame in Bhairavnath's direction from the temple steps.

Bhairava and Devi, and often their myriad localized forms in the (Himalayan and other) landscape, became key foci for what have come to be termed systems of Shaiva Tantra. The term Tantra has a complicated history that is difficult to summarize. Geoffrey Samuel $(2008,9)$ has offered a useful general definition:

a relatively coherent set of techniques and practices which appears in more or less complete form in Buddhist and Śaiva texts in the ninth and tenth centuries CE. This comprises a number of elements: elaborate deity visualisations, in which the practitioner identifies with a divine figure at the centre of a mandala or geometrical array of deities; fierce male and particularly female deities; the use of transgressive "Kāpālika"-style practices associated with cremation grounds and polluting substances linked to sex and death; and internal yogic practices, including sexual techniques, which are intended to achieve health and long life as well as liberating insight.

The Himalayan landscape in and around Kedarnath came to be understood as a potent resource for powering such tantric techniques, as several passages from the Sanskrit texts of the Kedarakhanda and the Kedarakalpa discussed later in this chapter attest.

\section{TRANSREGIONAL CONNECTIONS}

A famous story in the Mahabharata constructs the Himalaya as a place where the encounter with Shiva functions as the bridge between the North Indian plains and the non-Aryan worlds of the Himalaya. Arjuna, one of the Pandava princes whose saga drives the plot of the Mahabharata, journeyed to the Himalaya during the period of the Pandavas' exile in the forest. There Arjuna fought with a disguised Shiva, thinking him to be an indigenous local hunter, a kirata. Shiva revealed himself to a suddenly awestruck and devoted Arjuna and granted him an invincible weapon suggestively named "the weapon of the Lord of Beasts" (Sanskrit: Pashupatastra). ${ }^{12}$ The Garhwal Himalaya is one region where this encounter has been understood to take place, and it makes a degree of sociohistorical sense. By the middle of the first millennium CE, Garhwal had begun to function as both periphery (the edge of "the Land of Noble Ones," Sanskrit: aryavarta) where indigenous peoples lived who might possibly have migrated earlier from Central Asia, and center (the pure, remote Himalaya, home of sages, Shiva's home of Kailasa, and north of that Mount Meru). Kedarnath was one of the places that served to mark the boundary of the aryavarta, whose boundaries a powerful king might imagine that he could bring under his rule under optimal conditions (Sircar 1971, 11). 
Peoples at the time indigenous to Garhwal and Kumaon had already been interacting with many of the early Shaiva groups who had been coming from the plains for centuries, particularly Pashupata groups, and some regional rulers were Shiva devotees or supporters of Shaiva groups, particularly Lakulisha Pashupatas (M. Joshi 2007, 216-20; Dabarāl, n.d., 170-73). The Shiva temple of Gopeshwar in the Chamoli district of Garhwal is particularly important for charting this pattern of early connections to Pashupata Shaivism in Garhwal and Kumaon (M. Joshi $2007,224,227)$. Much of the social, ritual, and philosophical diversity found in the early Shaiva worlds across the subcontinent was also present in the Garhwal and Kumaon regions of the Himalaya. ${ }^{13}$ It is reasonable to assume that Kedarnath would have been one focal point for all of this, and that, along with other important old Shaiva sites in the region such as Jageshwar, Kankhal, Gopeshwar, Pandukeshwar, and Lakhmandal, it may have functioned as one of the nodes through which Shaiva groups from outside what we now call the central Indian Himalaya became connected to the region and interacted with each other. The work of art historian Nachiket Chanchani $(2015,2014,2012)$ on the presence of Shaivas in Garhwal and Kumaon offers useful material support for this point.

Many accounts of Garhwali history, including those sometimes told at Kedarnath, correlate the Brahminization of the region and the establishment of monastic linkages to Badrinath and Kedarnath with the figure of the famous philosopher Shankara. ${ }^{14}$ Brahminization, or (to use the term initially developed by anthropologist M.N. Srinivas to describe what he observed among the Coorgs, a South Indian tribal group) "Sanskritization," refers in a general sense to "a process by which the group gradually adopted characteristics of surrounding 'Sanskritic' culture in order to raise its status in relation to those cultures" (Srinivas 1952; Samuel 2008, 78). ${ }^{15}$ This process often involved a transition to a social framework that valued the knowledge, status, and authority of Brahmins and valorized Sanskrit. While the historical realities are considerably more complicated, the visit of Shankara is popularly understood to have turned the character of the region in the direction of Shaivism (and to lesser extent, Vaishnavism) and away from the influence of Vajrayana and Mahayana Buddhism (Jain 1995, 21, 53). Shankara was one of the most famous and influential thinkers in the history of the subcontinent and in many circles was and is regarded as an avatar of Shiva. In addition to the profound influence on the development of (nondual) philosophical thought in South Asia ascribed to him, he is traditionally credited with the establishment of the Dashanami monastic order, one of the primary institutions that structure the lives, practices, and social worlds of Shaiva renunciants through to the present day. According to traditional sources, Kedarnath is one of the places where Shankara may have passed away (Clark 2006, 155). Govind Chandra Pande $(1994,52)$ places the dates for Shankara's life between 650 and 775 CE. ${ }^{16}$

The journey of Shankara into the Himalaya attests to the fact that entry into the "Shaiva Age" coincided with a rise in the popularity of yatra and the continued 
incorporation of peripheral areas like Garhwal and Kumaon into the emerging sacred geographies of the Puranic imagination, geographies that would be enacted through the practice of yatra (Nath 2009, 202-5). The practices that Puranic texts associate with yatra to specific tirthas often operated as syntheses of preexisting Vedic and Brahminical frameworks with other popular local and regional traditions. These practices included performance of the following at tirthas: "fire oblations ... meditation ... satiation of gods, sages and ancestors . . . ancestral rites ... austerities ... religious-gift-making," puja, listening to stories about tirthas to gain merit, yatra to the tirtha, circumambulation, shaving of the head, chanting and reciting of verses many times, and on occasion "religious suicide" (Nath 2001, 131-32). This list describes captures many of the practices found at Hindu pilgrimage places today.

By the tenth to thirteenth centuries Kedarnath was already well established as a place of pilgrimage and a site of royal patronage (V. Pathak 1987, 92-93; M. Sharma 2009, 53; Dabarāl, n.d., 478-85; Naithānī 2006, 179-82). Kedarnath had become part of the network of tirthas linked by what Diana Eck $(2012,39)$ has called a "complex grammar of sanctification" that spread throughout the subcontinent, a web of paths and places linked by devotion, politics, custom, and divine power. Kings were traveling to Kedarnath, and thousands of kilometers to the south poet-devotees such as Campantar had already been singing their devotion since the seventh century and mentioning Kedarnath in the Himalaya. Local rulers in the tenth to thirteenth centuries were sponsoring temples that incorporated their kingdoms into larger-scale sacred geographies that, according to Chanchani (2015, 36 ), enacted "an evolving idea of India . . . a cohesive geo-cultural entity extending from the shores of the Indian Ocean up to the snow-capped Himalayan peaks" as a way to strengthen their rule (see also M. Sharma 2009, 21-22). Rulers forged these connections by supporting temple construction and maintenance in ways that drew artisans from outside the region, by taxing trade and agriculture, by carrying out pilgrimages that linked them to the Gangetic plains, and by using land grants to lure Brahmins from the plains. Chanchani $(2015,35)$ shows that this pattern may be fruitfully used to understand certain aspects of the situation in Garhwal and Kumaon and suggests that it can be applied to understanding the development of the famous shrines of Kedarnath and Badrinath.

\section{NATHS AND VIRASHAIVAS}

Two additional Shaiva communities became significant in Garhwal between the thirteenth century and the beginning of the nineteenth century, both of which displayed a distinctive understanding of the textures of the place-deity-devotee relationship. By the sixteenth century, the Naths had a strong presence. ${ }^{17}$ David White $(1996,97)$ has noted connections between the Nath-Siddhas and the Pashupatas and Kapalikas. One of the important differences, however, in the practices 
and doctrine of the Naths was the internal visualization of the often externally transgressive practices associated with the Pashupatas and Kapalikas rather than actual external physical performance of those practices. Naths also differed from earlier Shaiva groups by orienting their tradition around a series of gurus, beginning with the primordial guru Shiva and thence the legendary human Matsyendranath (Macchandar) and his disciple Gorakhnath (Mallinson 2009; White 2015). For Naths, Kedarnath and Gaurikund are significant as a set of places where the union of Shiva and the Goddess and their powerful bodily fluids are especially accessible (White 1996, 196, 245-46). The material power of the ground and water could serve as fuel for the transformation of what David White (1996) has termed "the alchemical body." The Sanskrit text Kedarakhanda (to be distinguished, as we will see, from the Kedarakhanda section of the Skandapurana) places an ashram of Gorakhnath near Gaurikund, and King Ajay Pal was connected to the Nath tradition and to the Nath yogi Satyanath and gave him land, an event that can be approximately dated to the sixteenth century (Dabarāl, n.d., 106, 182-83; White 1996, 112 and 407-8n177; Rawat 2002, 34; Negi 2001, 17). Today there is a dense network of Nath shrines and sites of importance for Nath yogis in Garhwal and Kumaon (Kukaretī 1986).

The second of these more recently prominent Shaiva groups is the Virashaivas. They are the pujaris of Kedarnath today and assert that they have held this position for millennia since having received the region of Ukhimath (originally termed by them "Ushamatha" in memory of a marriage between Usha, daughter of Shiva's demon devotee Banasur, and Krishna's grandson Aniruddha) as a gift from Janamjeya, the great-grandson of the Pandava prince Arjuna (Hiremath 2006, 12, 28-29). ${ }^{18}$ According to the versions of Virashaiva tradition reported in the modern-day Kedarnath valley, the Virashaiva teacher Ekorama, one of five primordial incarnations who first emerged from each of the five faces of Shiva's linga, founded Kedarnath. ${ }^{19}$ Kedarnath is described as one of the five headquarters (Hindi: math, or peeth) of what Virashaivas in the Kedarnath valley refer to as the Virashaiva tradition, along with Rambhapuri, Ujjain, Shri Shailam, and Varanasi. It is known as the Vairagya Peetha today (Hiremath 2006, 3). Each math is led by a jagatguru. Bheemashankaralinga Shivacharya Bhagavatpadaru is the current Kedarnath jagatguru and the rawal of Kedarnath. His students (Hindi: cela) serve as the pujaris for Kedarnath, the Vishvanath temple in Guptkashi, the Madmaheshwar temple in the Madmaheshwar valley, and the Omkareshwar temple in Ukhimath. ${ }^{20}$

It is known that the earliest versions of the diverse groups today termed Virashaivas, who tend to be connected to regions today known as the states of Karnataka and Maharashtra, were found in many of the same places as the Kalamukhas, but the relationships of these groups are not wholly clear (Lorenzen 1988; Michael 1983; Leslie 1998; T. Smith 2007, 305). Recent scholarship about the history of the Virashaivas suggests that the idea of a "Virashaiva" identity, today 
often synonymous with or connected to the label "Lingayat," may have solidified only in the fifteenth and sixteenth centuries (Shobhi 2005, 8, 252-59, 269, 295-96). The early recorded history of this group involves a complex relationship to other Shaiva groups. This set of traditions displayed a different relationship to Shaiva places than the Naths: many of the early voices in this set of traditions contrasted the static (sthavara) nature of place-based temple-centric ritual with the moving (jangama) and fluid experiential world of the embodied, wandering Shiva devotee devoted to a personal and portable linga (Ben-Herut 2016, 2015; Leslie 1998; Lorenzen 1988; Michael 1983). ${ }^{21}$ The goal of the devotee was the ultimate experience of a nondual Shaiva reality in which devotee and deity both merged and transcended the binary imposed by the sense of devotee-deity relationship.

\section{PREMODERN SHAIVISMS IN GARHWAL}

AND KUMAON

While there are many importance differences among the worldviews and practices of these different Shaiva groups, their common ground should also be emphasized. Keeping this idea of common ground in mind, I think that much can be understood about earlier relationships of the groups sometimes known today as Virashaivas to Kedarnath through comparison with the social history of another jyotirlinga: Shri Shailam in Andhra Pradesh. As Prabhavati Reddy (2014, 78-81) has documented, Sri Shailam served between the seventh and sixteenth centuries as a point of meeting and mingling among local, regional and transregional Shaiva traditions that included the Pashupata, Lakula, Kalamukha, Lingayat, Kapalika, southern Shaiva Siddhanta, and Smarta Shaiva traditions (see also White 1996, 110). Something similar may have happened in Kedarnath.

It is clear that by the beginning of the nineteenth century Kedarnath was of significant concern for multiple lay and monastic Shaiva groups and a focus of the more general interest of Shiva-oriented yatris, kings, and renunciants from across the subcontinent who were engaged in practices of pilgrimage, devotion, rule, and patronage. It is also clear that there were myriad overlapping understandings and experiences of the presence, form, and nature of the Shiva felt to be present in Kedarnath. There were different, overlapping models for thinking through the relationship of the Shiva devotee to Shiva that could connect to Kedarnath: a relationship that would deepen infinitely, a relationship that would turn into mystical union, a relationship of infinite devotion, a relationship in which the devotee would become the god, a relationship that would produce power that could be used for material benefit, a relationship that would enable liberation from the prison of mundane existence, and a relationship that could recalibrate social relationships and political contestations for power and authority. Foundational stories and important ritual practices connected to Kedarnath, as we will now see, resonated across this entire range. 


\section{THE STORYING OF KEDARNATH}

Some of the most famous Kedarnath-related stories, part of the broader web of stories that frame places like Kedarnath, are found in the Shiva Purana, the bestknown and most commonly referenced Sanskrit text related to Kedarnath. Both in the Kedarnath valley and more generally, the Shiva Purana is one of the Puranic texts that is commonly recited and expounded in the context of multiday recitations (Hindi: katha). Recitations of the Shiva Purana often occurred in Kedarnath during my time there: in 2007 three were scheduled and two were performed. One of those performed was a very public recitation sponsored by the Samiti, and the other was a private recitation sponsored by a group of yatris who brought their own reciter with them and who resided in Kedarnath for the duration of the katha. Texts of the Shiva Purana are available for purchase in the bazaar. Also present in the Kedarnath bazaar in 2007, but to the best of my knowledge in only two shops, was the previously mentioned tantric text of the Kedarakalpa. There is also a third text of critical importance for understanding Kedarnath: the Kedarakhanda. This text claims to be the first section of the previously mentioned Skandapurana (which bears the same title) but in reality differs in content, focusing almost completely on providing a description of the sacred geography of Garhwal. A discussion of key passages in these three texts shows how Kedarnath functions as a place that (again remembering Edward Casey's notion of place as a kind of intersubjective gathering) gathers and integrates the different Shaiva understandings of Shiva's present in the Himalayan landscape and how devotees might engage the power of the deity/place that has been the subject of the chapter thus far.

\section{THE SHIVA PURANA}

In one of the Shiva Purana's most substantive passages mentioning Kedarnath we meet a dual incarnation of Vishnu in the forms of the sages Nara and Narayana, who are carrying out penance and ascetic practice. ${ }^{22}$ More specifically, they are worshipping Shiva. After a long time Shiva, pleased with their devotion, offers them their choice of boon. The two sages reply: "O lord of gods, if you are delighted, if the boon is to be granted by you, O Śiva, stay here in your own form [Sanskrit: svena rupena] and accept the devotion of your devotees." As the passage continues, we find out that the setting of this episode is "Kedāra": "Thus requested, lord Siva himself stayed in Kedāra on the Himavat in the form of Jyotirlinga. He was worshipped by them for helping the worlds and for appearing in the presence of the devotees." A bit later in the same passage the Pandavarelated story appears:

It was he who on seeing the Pānḍavas assumed the form of a buffalo, having recourse to his magical skill and began to run away. When he was caught by the Pāṇdavas he 
stood with his face bent down. They held his tail and implored him again and again. He remained in that form in the name of Bhaktavatsala. His head portion went and remained fixed in the city of Nayapāla [Nepal]. The lord stood in that form there. He asked them to worship him in that trunkless form. Worshipped by them, Siva remained there and granted boons. The Pāṇavas went away with joy after worshipping him. After obtaining what they desired in their minds, they were rid of all their miseries.

There in the shrine of Kedāra, Siva is directly worshipped by the Indian people. He who makes a gift of a ring or a bracelet after going there becomes a beloved of Siva. He is endowed with the form of Siva. On seeing that form of Siva, a person gets rid of sins. By going to Badari forest he becomes a living liberated soul. On seeing the forms of Nara, Nārāyaṇa, and Kedāreśvara, undoubtedly he can achieve liberation. The devotees of Kedāreśa who die on the way are released from rebirth. No doubt need be entertained in this respect. Going there, with pleasure, worshipping Kedāreśa and drinking the water there, a person is released from rebirth. O Brahmins, in this Bhārata country people should worship with devotion Nara-Nārayaṇeśvara and Kedāreśa. Although he is the lord of the universe still he is particularly the lord of Bhārata. There is no doubt that Siva Kedāra is the bestower of all desires. O excellent sages, I have narrated to you what you have asked for. On hearing this narrative the sins disappear at once. No doubt need be entertained in this regard.

Different ways of talking about Shiva's form coexist in this passage. It is possible to see a tension here between the idea that Shiva is hyperpresent in his Himalayan abode and the well-documented character trait that Shiva is a god, as Don Handelman and David Shulman $(2004,220)$ have put it, whose "body is itself a dense mass of joyfulness" but whose "habit" is to "slip away." This story fixes God's desire to slip away in the soil of the place itself. True darshan of Shiva is, to extend the interpretive path of Handelman and Shulman, darshan of his desire to be less than fully present and at the same time, of his dynamic flow both utterly into and away from what is happening. In one sense this is why he initially distances himself from the Pandavas-to bring them to the place where his absence is most present and powerful. These passages suggest that Shiva is both eminently available, graciously manifesting at the request of the sages Nara and Narayana, and at the same time reticent, liable to run away and in need of persistent supplication. This passage, in what is now evidently a persistent theme, also emphasizes the importance of drinking water in Kedarnath. I often heard this verse quoted in Kedarnath in 2007 and 2008: "When one has drunk that Kedar-water that transcends samsara and cuts the net of papa, there is no rebirth. One will not be bound in a womb but go to the eternal state" (Lakșmidhara 1942, 8:230). ${ }^{23}$

The importance of the Himalaya also hovers in the background of this story. Amid many of the cultural geographies of the natural world in South Asia, the Himalaya has stood as a region apart. It has been the zone of purificatory power to which ascetics retreat to meditate, following in the footsteps of the famous sages of 
the past, as well as a set of culture areas with different local deities more connected to Tibet and Nepal than to the Gangetic plain and the rest of the Indian subcontinent. It is the source of the Ganga and Yamuna rivers. The Himalayan mountain Kailasa, famed as Shiva's most preferred place of residence, has been understood by many strands of Hindu, Buddhist, and Jain traditions as Mount Meru, center of the world (Eck 2012, 199), and is itself a famous pilgrimage destination. Specifically, within the borders of kedaramandala, the karmic fruits of meritorious action are multiplied. As William Sax $(2009,53)$ has observed, the Garhwal region of Uttarakhand demonstrates an especial density of "world famous pilgrimage places" that are mentioned in different Puranas and versions of the Mahabharata. The Kedarnath valley is replete with references to ancient sages such as Agastya (in the village of Agastmuni) and Jamadagni (in the village of Rabi just above and west of Fata). There is a public debate every year in the village of Kavilta (located behind Kalimath) about whether Kavilta is the natal place of the famous Sanskrit playwright Kalidasa. Kalidasa gave the Himalaya pride of place in one of the most famous dramatic works of Sanskrit literature, The Birth of Kumara:

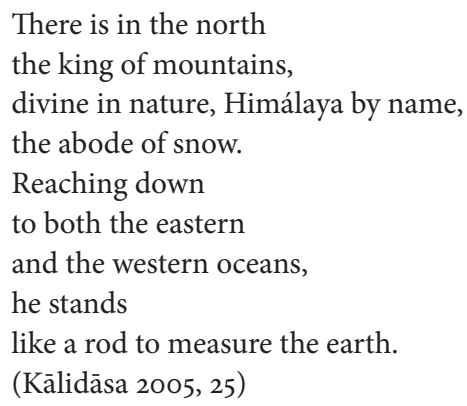

In the worlds of Puranic narrative the Himalaya is both geology and characterShiva's preferred residence and his father-in-law. Arjuna meets Shiva in the Himalaya in the guise of a tribal hunter and, after being humbled in a contest with him, becomes his devotee and is gifted with the Pashupatastra weapon in return. The Himalaya is the location for some of the most important stories that provide insight into Shiva's nature. It is in the daruvana, the Himalayan forest of pines, that Shiva decides to teach a harsh lesson to a group of sages who have been ignoring him and mindlessly overfocusing on arduous ascetic practices. Vishnu, in his beguiling female form of Mohini, distracts the sages while Shiva goes to see the wives of the sages in their village. Upon his arrival they all fall straightaway into uncontrollable desire. The sages, realizing what has happened, use their sacrificial fire and generate a series of world-ending weapons with which they attack Shiva, culminating with (in the fourteenth-century Kanta-puranam version of this story) the production of the destructive being Muyalakan. Shiva then begins to dance his tandava dance on the head of Muyalakan, and the power of the sages 
is destroyed, along with the egocentric karma that created the situation (Handelman and Shulman 2004, 4-14). This image, of Shiva who is the Lord of Dance (Sanskrit: Nataraja), becomes one of the famous modalities of Shiva's presence in the world.

The Himalaya is also the backdrop for many of the central episodes in the relationship of Shiva and Parvati, some of which are held to have happened near Kedarnath. Just before the trailhead at Gaurikund one may stop at the temple of Munkatiya, where Shiva cut off the head of Ganesha as he tried to prevent Shiva from seeing Parvati before she was ready after her bath. Gaurikund, as Diana Eck $(2012,226)$ has pointed out, is according to some where Parvati, also known as Gauri, performed the "severe spiritual austerities" necessary to convince the ascetic god that he should marry her. With the help of Kama, the god of desire, Parvati finally agreed and their union produced a son, Skanda, who was able to kill the otherwise invincible demon Taraka. These stories establish the complexity of Shiva's identity as both ascetic and family man and ground that complexity in a kinship relation with the Goddess and the mountains.

\section{THE KEDARAKHANDA}

There are also region-specific texts and story cycles that localize these Puranic stories in specific regions. The Kedarakhanda is one such text- a medieval/early modern Sanskrit text that focuses on the religious geography of the region known today as Garhwal. ${ }^{24}$ When one examines the Kedarakhanda with a Kedar-centric eye, it becomes apparent that Kedarnath is effectively a focusing node for the broader power of the region. The first story about Kedarnath in the Kedarakhanda immediately follows an account of the descent of the Ganga and the elucidation of her multiple watery flows.

Vasishta said: ${ }^{25}$

Having heard this excellent story, Parvati, filled with devotion, said to her husband Shiva, "God of Gods, ruler of the world, you are he whose grace is the final objective of devotees. You have now told me about the ten streams of the Ganga. Abode of all that which is, tell me the names and greatness of the country where those flows went. Tell me their greatness in detail; I want to hear this now. Where did those Brahma-arisen waters meet? Tell more about the greatness of those places. I am your devotee, Lord of Gods, you alone are dearer to me than breath. People do not conceal from those who love them. Lord, you alone are the maker of the world, the upholder of the world. By you alone, Lord of Gods, are these three worlds permeated entirely. Tell in detail in which countries are the ten flows of the Ganga."

Parvati's questions are similar in form (if not fully in import, considering the metaphysical underpinnings of a dialogue between Shiva and Parvati/Shakti), to 
those that yatris might ask their tirth purohit. They also remind the reader about Shiva's complicated identity as both ascetic and husband.

The Lord said:

Listen, Devi, best of women, matchless one-I will answer what you have asked, and it has never been told to anyone else before. Effort should be made to keep this marvelous and wonderful secret hidden. By the mere sight [of such places] millions of papa-generating actions are burnt up as if by fire, ruler of the ruler of the gods. Hear, Devi, how once the god-sired Pandavas, the famous and mighty sons of great-souled Pandu, were disgraced by their killing of their own lineage and afflicted by their murder of their own guru. Having killed Drona and all the others, they were greatly troubled, and with their hearts burning and greatly agitated with grief, with all their deeds come to foul ends, they sought refuge with Vyasa. Possessing minds into which impurity had already entered, they said to great-souled Vyasa: "Blessed Vyasa, all of us have come for refuge with you. How can we, Brahman, whose selves are now full of wickedness [Sanskrit: papa], attain liberation? We are disgraced by the killing of our own lineage and afflicted by the murder of our guru. You are our only refuge; give us a clear command. Brahmin, by what action can we attain the highest state? Having taken pity on us because we are your descendants, tell us this."

Vyasa said:

"You Pandavas who are killers of your lineage, listen! What is generally valid as a cure for all cases does not hold for those who have killed members of their lineage unless they go to the abode [Sanskrit: bhavanam] of Kedar. Go there! That is where Brahma and other gods who are desirous of the darshan of Shiva stay established in purificatory ascetic activity [Sanskrit: tapas], purified of their actions as they carry out the highest tapas. That is where Ganga is, the most eminent and chief of the numerous rivers. That is where the Lord Shiva lives, along with his numerous mighty followers and kings. That is where the gods, along with the gandharvas and yakshas and rakshasas and bulls, have their sport every sunset of one half of the month of the scorpion. Many instruments sound there and the chanting of the Vedas is heard. That is the place where those who are dead become Shiva, without doubt. Who can describe the greatness of that area [Sanskrit: kshetrasya]? He who has given himself over to numerous tirthas and remembered that area will get liberation. Go to that divine place [Sanskrit: tridashasthanam] known as the Great Path. That is the best place for expiation of the papa of killing Brahmins."

Of distinct importance in this paragraph, and throughout many parts of the Kedarakhanda, is that there is a good degree of semantic overlap between the region of Kedara (Sanskrit: kedaramandala), roughly conforming to modern Garhwal, and the area of Kedarnath proper. In this small section alone one finds a number of different place words that set up this overlap: bhavana, sthana, kshetra, and later on sthala. This variation of different location-terms is typical in passages 
from the Kedarakhanda relating to Kedarnath. We also see that the story dwells on the weight of the papa carried by Draupadi and the Pandavas. Further, the passage clearly functions as an example of the Puranic mechanisms of localization and incorporation: semidivine (Sanskrit: gandharva, yaksha) and demonic (Sanskrit: rakshasa) beings, many of whom may have been preexisting local deities with connections to the natural world or to a specific locale, are here incorporated into Shiva's world as his followers. ${ }^{26}$

The Lord Shiva said:

“Thus Vyasa spoke. Having heard, the Pandavas delightedly reverenced him, circumambulated him, and went to Mount Kailasa. They lived there and attained the highest condition. The tirthas by whose selfless worship [Sanskrit: seva] those mighty ones became pure, the attainment of that place is difficult even for the gods. It is fifty yojanas [Sanskrit: a Vedic unit of measurement] by thirty yojanas, and this place is whence one goes to heaven - that mighty place is not earthly. From the border of Gangadvara to the white mountains and from the banks of the Tamasa to the underside of Boddhacala is known as the auspicious region of Kedara, a raised place [Sanskrit: sthala] separate from the world."

This first message makes no specific reference to Kedarnath but rather delineates the region as a whole. This recalls my stipulation in the Introduction that we may productively view Kedarnath as a complex eco-social system with fuzzy edges.

The second story (Nautiyal 1994, 144-47) involves a development whereby living creatures transform to Shaiva beings because of their proximity to Kedara, a phenomenon described in the Puranas as "the state of having the same form as" (Sanskrit: sarupata) a specific deity. ${ }^{27} \mathrm{~A}$ hunter in pursuit of quarry finds himself in a forest that lies, unbeknownst to him, at the edge of the Kedara region. An inexplicable darkening of the sun has just caused him to narrowly miss shooting a golden deer (who, he did not know at the time, was the sage Narada). He sees a snake eating a frog and approaches to investigate. "Just as he went closer, he saw a frog in a hole being quickly swallowed by a large snake. Just as the black snake swallowed this frog, the frog turned into a noble trident-bearing entity wearing a serpent as a sacred thread, with resplendent locks, bearing a half-moon, glorious like Kailasa, dancing, adorned by his followers, blue throated, wearing the skin of an elephant." As the passage proceeds, the hunter encounters another wondrous sight that challenges his mental faculties even more: the apparently spontaneous transformation of a tiger killing a deer. The deer becomes Shiva and the tiger, killed by another hunter, becomes a bull on which Shiva then seats himself. The hunter is rescued from mental breakdown by meeting the sage Narada and learning that these transformations are happening because he is in the neighborhood of Kedara. As living beings cross the event-horizon of the tirtha/region, they achieve the sarupata of Shiva. 
This theme of the fluidity of identity and form brought on by arrival/residence in the Kedara region/tirtha may be found in many places in the text. The Kedarakhanda tells of a merchant couple who adopt a river and treat the river as a daughter, or a merchant who takes a mountain as his son when he is unable to become a father through normal means (Nautiyal 1994, 787, 779). One reads about beings and natural entities inhabiting the region who were previously wicked, from a lower social class (Sanskrit: varna), or a demon (Sanskrit: rakshasa) or about pious Brahma-rakshasa who have taken up residence in the region (sometimes in groups of ten million) until they may achieve final liberation (Nautiyal 1994, 163, 542). One river was once a low-caste human (Nautiyal 1994, 700-702).

These stories paint a picture of the Kedara region as a place whose extraordinary purificatory power creates a fluid continuum among different kinds of people, demons, the natural environment, and deities rather than a sharp distinction among different classes of entities. This power both depends on the presence of Shiva and is independent of that power and connected to the Himalayan region itself. Yatris in Kedarnath often told me that that the results of meritorious action performed on yatra would be exponentially multiplied by the power of Kedarnath or of the region. A sense runs through these accounts of the Himalaya as a region that is somehow in motion and whose form can change. This, of course, resonates with the fact that the Himalaya are young, geologically and seismically active. The mountains can change. Also emergent is the theme that this region is somehow cut off or separated from the North Indian plains, not just in geographic but also in sociocultural and even existential terms. Life is different in the mountains. Travel is difficult, and the mountainous landscape can impose its own rules. This theme runs through to present-day understandings of what it means to be pahari, a mountain dweller as opposed to someone from the plains.

The geographic survey of the Kedarnath valley in this part of the Kedarakhanda text eventually comes around to what are known as the Panch Kedar, the five Kedars (of which Kedarnath is the most famous). Toward the end of this section the narrative returns to Kedarnath and the Pandavas, with Shiva as the narrator.

"Listen, Devi, best of women, Parvati, to my tirthas. There the excellent Vaitarani flows, who causes the crossing over of ancestors. ${ }^{28}$ There by the act of offering food to the ancestors [Sanskrit: pindadana] one gets the fruit of a hundred thousand Gayas. There is a pleasing Shiva-face there bearing all sorts of adornments. By its darshan people are liberated. Formerly, I, the ruler of the gods, was fiercely and persistently sought by the Pandavas, all connected to the killing of members of their lineage, for the purposes of purification of their papa. Seeing them, I went to the region of Kedar. They followed behind me for a very long way. Seeing them coming close, I entered the ground. Seeing me near, they came behind me, and in the location known as Kedar, Goddess, they touched my auspicious back. By that mere touch they were liberated from the murder of their lineage, and my back part, Parvati, is established 
there even today. The lord of Kedara is reported in all the three worlds as liberationbestowing." (Kedarakhanda 52.1-8, ed. Nautiyal 1994, 177-78)

This passage, a different version of which we have already seen as part of the narration offered by Tiwari-Ji and as part of a passage in the Shiva Purana, indexes the most famous and most-often told stories about Kedarnath that one hears today. In it, the persistence of the Pandavas is what causes Shiva to dive into the ground, thus activating his specific, hyperefficacious presence in Kedarnath. Yet even as we read this we recall that Shiva is telling this story to Parvati as part of a longer description about Garhwal in which Shiva effectively functions both as pilgrim guide and as the ultimate object of the aspirations of the devotee who journeys into the region. The relationship of Shiva and Parvati and their presence in the Himalaya is much deeper, broader, and infinitely longer than this brief account, as most readers would know. It is part of the play of conjoined Shiva-Shakti to listen to stories about their own true natures. Shiva's presence in Kedarnath is both historicized and ahistorical. This version also enshrines an important feature of the place-it is a place defined by the mark (Sanskrit: linga) of Shiva's present absence, a shape that tells us that the hyperpresent god is on his way to somewhere else. This story, this myth, tells us that grasping Shiva's presence in this place is difficult; it does not allow us to separate out stories of place from narratives of self. These stories, I think, rhetorically self-signal the limits of what can be expressed about the nature of the god and the potential for self-transformation in the place.

The second half of the Kedarakhanda focuses on a site-by-site elucidation, with digressions, of important shrines and natural features in the area. The geographically localized bulk of the text discusses the region of Garhwal in detail. Here we see charted a tantric geography in which the ability of many different locations to generate supernatural powers (Sanskrit: siddhi) and transform matter is exactingly detailed. Sites connected to the Kedarnath area in this regard include Retas Kund, the pool of quicksilver/semen in Kedarnath (Sanskrit: retasa, of alchemical importance to Nath-Siddhas, as noted by David White), red-colored water that turns metals to gold, and a site near the ashram of Goraksha where one can attain the ability to create pearls by touch (White 1996, 246). The presence of Bhairava and Kali are noted, as is the especial efficacy of the area for the funerary rituals of shraddh and the ability of contact with the place to cause a linga to grow in the heart (Nautiyal 1994, 148-53). There are, in the geographically specific bulk of the text, numerous enjoinders for animal sacrifice, usually when the subject of the text is a form of Devi, the Goddess (Nautiyal 1994, 796, 749). The persistent presence of Bhairava and forms of the Goddess, particularly fierce forms such as Kali and Bhairavi, is a reminder of one of the common features of Himalayan religious cultures that marks Garhwal-the dense intermingling of Shaiva and Shakta traditions with the local deities of the region, deities who are often understood as forms of Bhairava or Devi. The Kedarnath locale, and kedaramandala 
more generally, are understood to be infused with tantric power. This is important to keep in mind because it helps in understanding why in and around Kedarnath the temple is not the sole focus of religious attention.

\section{THE KEDARAKALPA}

The final Kedarnath-related text to be considered is the Kedarakalpa, a late tantric text of uncertain date that exists in two published versions. ${ }^{29}$ As discussed in the previous chapter, the Kedarakalpa serves as a guidebook for the reader whose goal is to walk into the physical Garhwal Himalaya and then, while remaining in his or her physical body, to walk to Kailasa and/or liberation. In this text it is possible to see how the efficacious power of the landscape and water accelerates the transformation of the devotee. In the Khemaraja Shri Krishnadasa edition of the Kedarakalpa, the text begins with four chapters of instructions for ritual preparation before commencing the main topic of the first half of the text: Shiva's description (first to Skanda and then to Parvati) of the immense potency of different sites in the Kedarnath area and the importance of drinking water (with numerous and diverse ritual specifications) at each site.

The story of the journey of a group of five tantric practitioners (sometimes called saddhakas, sometimes siddhas) who are walking from the world of death (Sanskrit: mrtyuloka) to the place where Shiva resides (Sanskrit: Shivalaya) is gradually woven into this overview of the potent ritual cartography of the Kedara region. The saddhakas drink water from important water sources and use the aghora mantra to protect them along the way in a journey that recalls that of the Pandavas. Jan Gonda $(1963,263)$ has translated the aghora mantra in this way: "Om, be there adoration to thy reassuring manifestations, O Rudra, and to the terrific ones, to the (manifestations) which are (at the same time) reassuring and terrific, O Sarva, to all these (manifestations) in all respects." The saddhakas refuse the offers of several kings and deities to tarry in a specific realm, enjoy themselves for hundreds of years, and then be reborn into an advantageous birth. They keep their focus on Shiva and keep moving north. Thus the idea of walking to Kailasa in one's own body frames both the popular practice of Himalayan yatra and the more esoteric practice of journeying into the Himalaya armed with mantras. The emphasis through the text on the importance of drinking water in specific places is another embodied bridge between the esoteric and the exoteric that resonates through to the present day. This yatra into the kedaramandala can be understood as both inner journey and outer journey, both secret and public, for both the initiate and the noninitiate.

Returning to the Kedarakalpa, in the section of the text that specifically describes what one should do in Kedarnath proper we find the instruction that the visitor to Kedarnath should performatively become a bull and drink water, 
an act that recalls the practices of the Pashupatas discussed earlier in the chapter (Kedarakalpa 6.1-26, ed. Viśālmaṇi Śarmā Upādhyāy 1952, 24-29). After bathing in the Mandakini River and performing a series of ritual preparations, one is enjoined to face in the northeastern direction, drink water three times from the left hand and three times from the right hand, and then get down on all fours like a bull, make sounds like a bull, and "drink like a bull." ${ }^{\circ}$ While doing this, one is to recite a Goddess-focused mantra that the Hindi translation is reluctant to reproduce, instead saying one should speak "unmanifest/unknown words" (Hindi: "avyakt shabd kar ke" in the Hindi commentary on lines 6.17-18) and then the words "I alone am Brahma, I am Vishnu, and thus also Shiva" (Kedarakalpa 6.19, ed. Viśālmaṇi Śarmā Upādhyāy 1952, 28). That is to say, the person ritually becomes Brahma, Vishnu, and Shiva while acting like a bull drinking water, an act with clear continuity to the earlier ritual practice frameworks of the Pashupatas. ${ }^{31}$

\section{APPROACHING THE LORD OF KEDAR}

Shiva's presence in Kedarnath is a self-manifest, pyramidal, mountain-shaped, rock-shaped place, a linga of light, and shaped like a buffalo. This presence does not lend itself to consistent description, but there is a persistent pattern, across time and language, to how different accounts of Kedarnath concentrate in a fuzzy and powerful way on the textures of how he is part of the place. We may conclude from the intricacy of rhetorical effort in this regard that as an abode of Shiva, Kedarnath poses and has posed a challenge to language. The significance and power of Kedarnath as a specific location spread out in variable fashion. In the Kedarakhanda numerous places of power in and around Kedarnath proper have the potential to become the objects of efficacious practice: rivers, kunds, valleys, lingas, rocks, and the environment more generally. The Kedarakhanda demonstrates a consistent refusal to distinguish in any final sense between Kedarnath and the region of Kedara (modern-day Garhwal) more generally, and it suggests a continuum of human, animal, and physical environment with significant overlap. This, I would argue, can be understood as a particular form of eco-social sentiment, a sentiment that regards human affairs as one part of a broader ecosystem. The Kedarakhanda invites the visitor to the region on a journey into a land seething with material religious power, some of which demonstrates personality and some of which does not. In the Skandapurana the presence of Shiva mingles with the waters of the Ganga and the efficacy of the Himalayan setting. The Kedarakalpa also emphasizes the power of flowing water in the Himalaya and reminds us that visitors to the region are not just traveling to see Shiva and be purified by the encounter but also in some sense on a journey to become the god himself.

Over the course of the accumulation of these historical and narrative layers we see several available models emerge for thinking through the form and flavor of 
human interactions with what is present at Kedarnath. Humans in Kedarnath may choose to think of themselves as following in the footsteps of the Pandavas, but the tone of the interactions of the Pandavas with Shiva in Kedarnath varies. Are they dharmic exemplars whose assiduous search for Shiva finally yields fruit, or are they seekers of liberation whose fierce determination and purpose lead them into an inappropriately intimate and violent encounter with Shiva that requires that they make redress? The darshan of Shiva in Kedarnath is the darshan of a deity whose face has turned away; the challenge posed by this unwillingness forces the Pandavas to resort to drastic measures, such as the threat of inappropriate behavior (forcing Shiva to pass between Bhima's legs, or striking him in frustration). Yet this Himalayan place of challenge enshrines a God who is hyperefficacious, hyperpresent, and able to cleanse papa that can be cleansed nowhere else.

Additionally, the Shaiva model allows the devotee to think of herself or himself as both creating a relationship with the god and attempting to become or join with the god, with all the complications that we now see this entails. Thus, when we imagine going to see Shiva in his Kedarnath abode, several questions arise. Are humans in Kedarnath on their way to becoming Shiva? How does the seeking of Shiva's darshan relate to somatically engaging the numerous powerfully charged sites in the Kedarnath valley? If the devotee wishes to become Shiva, and Shiva takes the form of a bull or a buffalo (as might the devotee as well, the Kedarakalpa reminds us), then what of the feeling of intense and sometimes violent (in the case of the blow from Bhima's mace) effort in many accounts of the Pandavas' interactions with Shiva when he is in his buffalo form? Are these not accounts that premise a devotional relationality of the human and the divine modeled in early form by the Pashupata, rather than the human becoming of Shiva suggested in the concept of sarupata? Is the wounding perhaps a self-wounding, a sacrifice of egobased self? Does human presence in Kedarnath constitute progress toward greater intimacy and an eventual merging with Shiva in which inner and outer worlds collapse, as it might be for a Virashaiva devotee, or is it an opportunity to move beyond the relationality of devotion and to access liberating power inside of one's self by using tantric techniques grounded in a place replete with divine material power? Or is it something else entirely?

Attention to questions of form and presence, a disciplined focus on the materiality of the different variables present in the eco-social system of Kedarnath, starts to frame the underpinnings of the present in Kedarnath. We start to see how an ancient web of narrative, practice, real and imagined landscape, place, and Shiva came to be and how the enmeshing of Shiva with his Himalayan environment has influenced the web in ways that are dynamically contingent and that constitute the beginnings of a persistent pattern. We see how this web creates narrative possibilities for framing physical presence in the place that break down the boundaries between self, body, deity, place, and religious power. Entry into this 
world makes the experience of being human much more permeable and, relative to other forms of sentience and material embodiment, more fluid. We acquire a view of Garhwal in which divine powers are geographically ubiquitous-continuously, materially, and efficaciously emergent. We observe that Shiva-in-the-Himalaya and the Himalaya itself are simultaneously moral and not moral. They reward virtue and devotion, yet at the same time their inherent religious power is such that they affect the unprepared as well. Let us now follow these complex patterns and the power they produce into the next chapter. 